\title{
Cloning of a Peroxidase Gene from Cassava with Potential as a Molecular Marker for Resistance to Bacterial Blight
}

\author{
Luiz Filipe Pereira ${ }^{1 *}$, Paul H. Goodwin ${ }^{2}$ and Larry Erickson ${ }^{3}$ \\ ${ }^{1}$ Laboratório de Biotecnologia Vegetal; Área de Melhoramento e Genética; Instituto Agronômico do Paraná \\ (IAPAR), Caixa Postal 481; CEP 86001-970; Londrina - PR - Brazil. ${ }^{2}$ Department of Environmental Biology; \\ University of Guelph; Guelph - On; Canada; N1G 2W1. ${ }^{3}$ Department of Plant Agriculture; University of Guelph; \\ Guelph - On; Canada; N1G 2 WI
}

\begin{abstract}
Cassava bacterial blight (CBB), caused by Xanthomonas axonopodis pv. manihotis, is considered one of the most important bacterial diseases of cassava (Manihot esculenta Crantz). In order to characterize the cassava genes involved in resistance to this disease, a genomic clone of a cationic peroxidase gene, MEPX1, was isolated by PCR from cassava cultivar MCOL 22. The DNA sequence of MEPX1 showed high homology with other plant peroxidase genes and contained a large intron typical of peroxidase genes. The predicted translation product showed a hemeligand motif, also a characteristic of peroxidases, as well as phosphorylation, myristoylation and glycosylation sites. The amino acid sequence had 75 \% homology with two Arabidopsis thaliana peroxidases. A Southern blot of 17 cassava cultivars, probed with MEPX1, showed multiple hybridization bands. Polymorphisms between cultivars generally reflected geographic origin, but there was also an association with resistance to CBB, indicating that MEPX1 could be a potentially useful marker for this trait.
\end{abstract}

Key words: Manihot esculenta, peroxidase, bacterial blight, Xanthomonas axonopodis

\section{INTRODUCTION}

Cassava (Manihot esculenta Crantz) is one of the most important tropical crops, being one of the main sources of calories for more than 500 million people in Africa and South America (Cock, 1985). Cassava bacterial blight (CBB), caused by Xanthomonas axonopodis pv. manihotis (Xam), is considered the most important bacterial disease of this crop with reports of yield reduction up to $92 \%$ in susceptible cultivars (Umemura and Kwano, 1983). The disease was reported initially in Brazi. However, presently it has spread worldwide. Plants employ a variety of defense mechanisms during a resistance response to pathogens, including the use of mechanical barriers, defense proteins and defensive enzymes. This change in the biochemistry activity of the plant cell includes, among others, the production of proteases, pathogens related proteins, and enzymes involved in the production of lignin, suberin, phenolic polymers and polysaccharides (Bowles, 1990). Peroxidases are enzymes that utilize $\mathrm{H}_{2} \mathrm{O}_{2}$ in oxidation reactions involving a range of compounds. An increase in peroxidase activity in plants is common during wounding, disease resistance and physiological stresses such as salinity, radiation, and pollution (Campa, 1991). Plant peroxidases can be directly involved in defense mechanisms acting as catalysts for the

\footnotetext{
* Author for correspondence
} 
polymerization of phenolic compounds to form lignin and suberin in the cell wall, which can act as barriers to block the spread of the pathogen in the plant (Fritig et al., 1987). The importance of peroxidases during plant resistance against pathogens has been demonstrated in interactions between rice and $X$. oryzae pv. oryzae (Chittor et al., 1997) and between cotton and X. campestris pv. malvacerum (Dai et al., 1996). Flood et al. (1995) suggested that peroxidases might also play an important role in CBB. Kpemoua et al. (1996) found that the production of phenolic compounds in the phloem and xylem of CBB-resistant cassava cultivars was significantly higher than in susceptible ones. There was also a higher accumulation of lignin and a greater formation of callose and tyloses in resistant cultivars. The presence of lignin, callose and tyloses in the vessels was reported to potentially obstruct the passage of the bacteria (Kpemoua et al., 1996). In a previous work, we described the activity of peroxidase during susceptible and resistant interactions between cassava and Xam and Xanthomonas cassavae (Pereira et al., 2000).

The objective of this work was to isolate and characterize genes involved in the response of cassava to Xam. We report here the identification and initial characterization of a cassava peroxidase gene fragment obtained by PCR, MEPX1, and its polymorphism among different cassava cultivars.

\section{MATERIAL AND METHODS}

Cassava cultivars used in this study are listed in Table 1 along with their geographic origin and level of resistance to CBB. Plants were vegetatively propagated in vitro from stem cuttings and transferred as plantlets to a growth room with day/night temperatures of $27 / 22^{\circ} \mathrm{C}$ and 12-h photoperiod.

The DNA sequences of eight peroxidase genes from different plant species were compared using the ALIGN program from PCGENE (Oxford Molecular, Oxford, England) to identify highly conserved regions. Potential primers were screened for homology with sequences in GenBank using the BlastN program (Altschul et al., 1990) to increase the probability of amplifying only peroxidase sequences. The two primers designed from the most conserved regions of related sequences were PX1: 5' CGTCTCCACTTTCATGACTGC 3' and PX2: 5'
GAAACCTACCGTGTGTGCACC 3', in sense and antisense orientations, respectively. PCR reactions were performed with $200 \mu \mathrm{M}$ of each $\mathrm{dNTP}, 10 \mathrm{mM}$ Tris- $\mathrm{HCl}, 5.0 \mathrm{mM} \mathrm{MgCl}_{2}, 50 \mathrm{mM}$ $\mathrm{KCl}, 1.5 \mathrm{U}$ of $\mathrm{Taq}$ polymerase and 200-400 $\mathrm{ng}$ of genomic DNA from cultivar MCOL 22. PCR conditions were $4 \mathrm{~min}$ at $94^{\circ} \mathrm{C}$, followed by 30 cycles of $1 \mathrm{~min}$ at $94^{\circ} \mathrm{C}, 1 \mathrm{~min}$ at $46^{\circ} \mathrm{C}, 2 \mathrm{~min}$ at $72^{\circ} \mathrm{C}$ and a final cycle of $5 \mathrm{~min}$ at $72^{\circ} \mathrm{C}$ in a GTC-2 thermocycler (Precision Scientific, Chicago, Il, USA). PCR products were visualized in $1 \%$ agarose gels stained with ethidium bromide, cloned into pGEM-T (Promega, Madison, WI, USA), and sequenced using the Taq Dye Deoxy Terminator Cycle sequencing kit (Applied Biosystems Inc., Foster City, CA, USA) on an ABI PRISM ${ }^{\mathrm{TM}}$ model 377 DNA sequencer. The translation product was predicted using TRANSL, CODING and SIGNAL programs from PCGENE and GENSCAN $\quad 1.0 \quad$ (http://CCR081.mit.edu/GENSCAN.html).

Table 1 - Origin and classification of cassava cultivars in relation to bacterial blight disease (CBB).

\begin{tabular}{|c|c|c|}
\hline \multicolumn{3}{|c|}{ to $\mathbf{C B B}^{1}$} \\
\hline BRA 70 & ND & Brazil \\
\hline CG1-56 & 4 & Colombia \\
\hline CG403-18 & 3 & Colombia \\
\hline CM 523-7 & $2^{2}$ & Colombia \\
\hline ESPETO & $\mathrm{S}^{3}$ & Brazil \\
\hline IAC 24 & 2 & Brazil \\
\hline MCOL 22 & 4 & Colombia \\
\hline MIND 8 & ND & India \\
\hline MIND 27 & ND & India \\
\hline MMAL 2 & 3 & Malaysia \\
\hline MMAL 48 & ND & Malaysia \\
\hline MNGA 1 & $1^{2}$ & Nigeria \\
\hline MNGA 2 & $\mathrm{R}^{4}$ & Nigeria \\
\hline MTAI 1 & 4 & Thailand \\
\hline MTAI 8 & 4 & Thailand \\
\hline SG 107-5 & 1 & Colombia \\
\hline VEN 70 & ND & Venezuela \\
\hline $\begin{array}{l}{ }^{T} \text { Classification } \\
\text { Agricultura Trop } \\
\text { was ranked on a } \\
\text { high. Cultivars } \\
\text { ND. }{ }^{2} \text { Personal c } \\
\text { CIAT Databank. } \\
\text { Filho et al., (200 } \\
\text { al., (1995) but no }\end{array}$ & $\begin{array}{l}\text { m CIAT (C } \\
\text { Colombia) dat } \\
-5 \text { scale where } \\
\text { no informatio } \\
\text { munication by } \\
\text { Susceptible cul } \\
{ }^{4} \text { Resistant cul } \\
\text { nked on } 1-5 \text { sca }\end{array}$ & $\begin{array}{l}\text { Internacional de } \\
\text { CBB susceptibility } \\
\text { very low and } 5 \text { very } \\
\text { t CBB are marked } \\
\text { a Guevara, Curator } \\
\text { eported by Vidigal } \\
\text { eported by Flood et }\end{array}$ \\
\hline
\end{tabular}


For Southern blot analysis, $10 \mu \mathrm{g}$ of DNA were double digested overnight with 2-3 units of restriction enzymes (EcoRI and BamHI), transferred to GeneScreen Plus ${ }^{\circledR}$ nylon membranes (DuPont, Boston, MA, USA) and hybridized with the peroxidase clone labelled with dCTP32- $\alpha$ using a random primer kit (Roche Diagnostics, Laval, Quebec, Canada). Hybridization was performed overnight at $42^{\circ} \mathrm{C}$ with $50 \%$ formamide, $2 \mathrm{X}$ SSC, $1 \%$ SDS $10 \%$ dextran sulfate, $5 \mathrm{X}$ Denhardt's solution and $100 \mu \mathrm{g} \mathrm{ml}^{-1}$ denatured salmon sperm DNA. The membranes were washed at low stringency as follow: $2 \mathrm{X}$ SSC at room temperature for $5 \mathrm{~min}$; $2 \mathrm{X}$ SDS and $1 \%$ SDS at $42^{\circ} \mathrm{C}$ for $30 \mathrm{~min}$; and $0.2 \mathrm{X} \mathrm{SSC}$ and $1 \%$ SDS for 5 $\mathrm{min}$ at room temperature. Following exposure of the membranes to X-ray film overnight, they were washed at higher stringency with $0.2 \mathrm{X}$ SSC and $1 \% \mathrm{SDS}$ at $63^{\circ} \mathrm{C}$ for $30 \mathrm{~min}$ and re-exposed.

\section{RESULTS AND DISCUSSION}

Several products were amplified from MCOL 22 DNA using the peroxidase primers PX1 and PX2, which were designed based on highly conserved regions of plant peroxidases. Three different sized PCR products were cloned, and one of these cloned PCR products of 1501 bp (MEPX1, GenBank Accession \#AF078691) showed sequence homology with other plant peroxidases and was analyzed in more detail. Two other amplified products, of approximately 700 and 900 bp, were partially sequenced, but did not have any homology with other peroxidases or any other sequences in GenBank. The DNA sequence and the predicted translation product of MEPX1 indicated the presence of two introns of 160 and 923 bp starting at nucleotides 31 and 392 respectively.

Cassava MEPX1
Arabidopsis 1
Arabidopsis 2
Spinach
Tomato
Rice

Cassava MEPX1 Arabidopsis Arabidopsis2 Spinach Tomato Rice

Cassava MEPX1 Arabidopsis Arabidopsis2 Spinach Tomato Rice
Myr/Pho Pho RLHFHDCFVEGCDAS ILISTKPGSKELAEKDAEDNKDLRVEGCESIRMAK 50

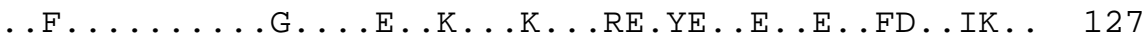
.MF .........VF.---ASEN.D......... . AGD.FDTVIK.. 112 ..F.............-QSTGTNT....HP..LS.AGD.FDTVIK.. 113 .M......R...G.V.LNFTSST.NQT..V.VP.QT..--.FSF.DGV. 111 ............V.L.---.QNAGPNVGSLRGFSVIDN-------.. 102 Myr/Pho

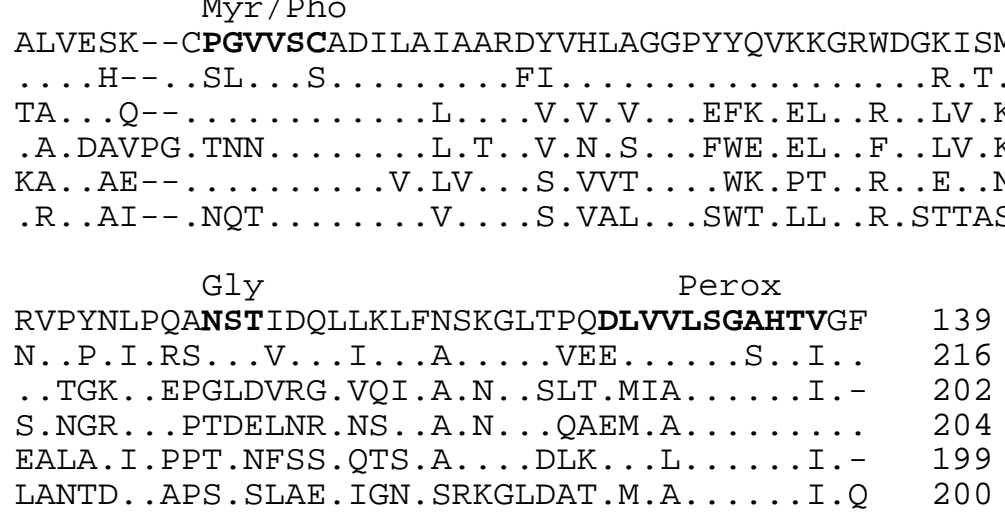

Figure 1 - Alignment of the predicted amino acid sequence of MEPX1 peroxidase of cassava and peroxidases of different plant species. Putative protein motifs are marked in bold as myristoylation (Myr), phosphorylation (Pho), glycosylation (Gly) and peroxidase signature (Perox). Dots (.) represent perfect homology with MEPX1.

The highest homology of MEPX1 was to peroxidases from Arabidopsis thaliana, Lycopersicon esculentum and Spinacia oleracea (Fig. 1). Individual homologies - similarities and identities - between MEPX1 and each peroxidase amino acid sequence are: 84 and $73 \%$ for
Arabidopsis 1 (Rounsley and Lin 1997); 71 and $56 \%$ for Arabidopsis 2 (ATP20- Welinder et al., 1986); 65 and 52\% for spinach (Simon 1993); 63 and 52\% for tomato (Botella et al., 1993); and 57 and $48 \%$ for rice (Chittoor et al., 1997). 
The $E$ values from BLAST analysis were respectively: $6^{-57} ; 2^{-37} ; 6^{-33} ; 6 \mathrm{e}^{-33} ; 5^{-37}$. The calculated pI (CHARGPRO, PCGENE) for those peroxidases indicated that all but one was cationic, and the calculated $\mathrm{pI}$ of MEPX1 indicated that it was a cationic peroxidase. A search for specific protein motifs in the predicted translation product revealed the presence of the heme-ligand on the $3^{\prime}$ end of the gene, similar to other peroxidases, as well as sites for phosphorylation, myristoylation and glycosylation (Fig. 1). Southern blots of 17 different cassava cultivar were probed with the MEPX1 clone (Fig. 2). When cassava DNA was digested with EcoRI and BamHI, most cultivars showed a unique band of 5 $\mathrm{Kb}$, but cultivars CM 523-7, MNGA 2 and MIND 8 also produced a higher molecular-weight band of approximately $8.8 \mathrm{~Kb}$. The presence of two bands, as well as the difference in the intensity of the hybridization signal, suggests a heterozygous condition for MEPX1 in these three cultivars. There was no difference in the number of the bands on the blots exposed after low or high stringency washes.

Cultivars MNGA 2 and CM523-7, which had the distinct $8.8 \mathrm{~Kb}$ band, are classified as resistant to
CBB. The same band pattern was observed for MIND8, whose resistance to CBB has not yet been reported. Cultivars Espeto, BRA 70, VEN 70, CG 403-18, IAC 24 and SG 107-5 showed bands of much higher molecular weight only. Among these cultivars, resistance to $\mathrm{CBB}$ has been reported only for CG 403-18, IAC 24 and SG 107-5, which are ranked 3, 2 and 1 , respectively, which represents a range of moderate (3) to high (1) CBB resistance. These three cultivars, plus the cultivar Espeto, both from South America, showed a banding pattern distinct from most of the cultivars coming from Asia or Africa. The distinct band pattern between cultivars from different regions has been demonstrated for other cassava genes that are involved in the plant defense mechanism (Pereira et al., 1999). Resistance to CBB in cassava has been described as a polygenic trait (Jorge et al., 2000, 2001). The association of an EcoRI/Bam $\mathrm{HI} 8.8 \mathrm{~Kb}$ hybridizing band with resistance to CBB suggests that MEPX1 may have potential as a molecular marker for disease resistance. It will be important to study the presence of MEPX1 in a segregating population from crosses of resistant cultivars, containing the MEPX1 band, and susceptible ones.

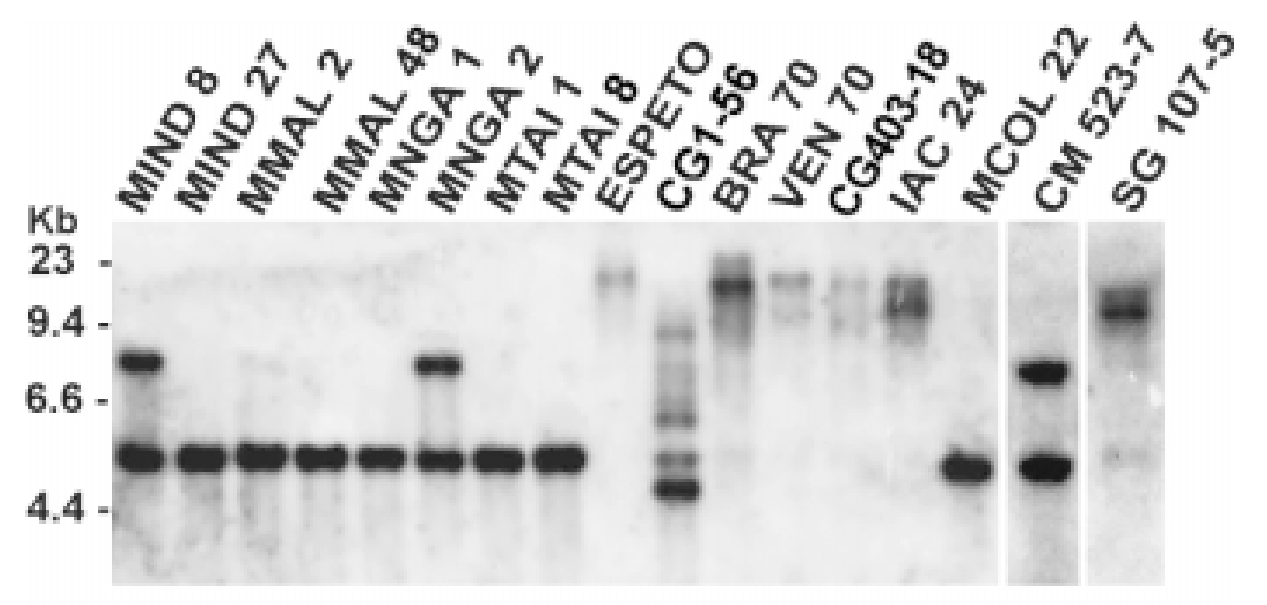

Figure 2 - Southern blots of DNA of different cassava cultivars (Table 1) double digested with EcoRI/BamHI, and probed with MEPX1. Positions of molecular weight markers in kilobase pairs are indicated to left of the figure.

This analysis can determine how closely linked the $8.8 \mathrm{~Kb}$ hybridizing fragment is to any disease resistance genes or to any QTL for CBB. It has been reported that $\mathrm{CBB}$ resistance was highly dependent of the interaction between cassava cultivars and Xam isolates (Restrepo et al., 2000), and MEPX1 could be useful as a marker for specific cultivar $\mathrm{x}$ isolate interaction. It would also be interesting to check this clone as a marker for resistance to cassava mosaic virus (ACMV), another important disease in cassava, since there 
are indications that the genes for resistance to both diseases are linked (Hahn et al., 1989).

\section{ACKNOWLEDGMENTS}

This project was supported by a research grant from the Natural Sciences and Engineering Research Council to L.E. L.F.P. was the recipient of a Ph.D. scholarship from CAPES. The authors are grateful to J. Kingswell for her help in the preparation of the manuscript.

\section{RESUMO}

Uma das mais importantes doenças da mandioca (Manihot esculenta Crantz) é a bacteriose, causada pela Xanthomonas axonopodis pv. manihotis. Visando caracterizar genes de mandioca envolvidos na resistência a esta doença, um clone genômico do gene de peroxidase (MEPX1) foi isolado por meio de PCR. A sequência de nucleotídeos apresentou homologia com outros genes de peroxidase de plantas, contendo um intron, típico de genes de peroxidase. $\mathrm{O}$ produto de translação apresenta o domínio heme-ligante, característico de peroxidases, assim como domínios de fosforilação e glicosilação. A sequência de aminoácidos teve $75 \%$ de homologia com genes de peroxidase de Arabidopsis thaliana. Análise em Southern blot de 17 cultivares de mandioca, usando MEPX1 como sonda, apresentou polimorfismos que, além de refletirem a origem geográfica do material, demonstraram associação com resistência ou tolerância a bacteriose, indicando que MEPX1 pode vir a ser explorado como marcador para esta importante doença em programas de melhoramento de mandioca.

\section{REFERENCES}

Altschul, S. F.; Gish, W.; Miller, W.; Myers, E. W. and Lipman, D. J. (1990), Basic local alignment search tool. Mol. Biol., 215, 403-410.

Botella, M. A.; Quesada, M. A.; Hasegawa, P. M. and Valpuesta V. (1993), Nucleotide sequences of two peroxidases genes for tomato (Lycopersicum esculentum). Plant Physiol., 103, 665-666.

Bowles, D. J. (1990), Defense related proteins in higher plants. Annu. Rev. Biochem., 59, 873-907.
Campa, A. (1991), Biological roles of plant peroxidases: known and potential function. In: Everse, J.; Everse, K. E. and Grisham, M. B. (ed.). Peroxidases in Chemistry and Biology. Florida : CRC Press. pp. 25-50.

Chittoor, M.; Leach, J. E. and White F. F. (1997), Differential induction of a peroxidase gene family during infection of rice by Xanthomonas oryzae pv. oryzae. Mol. Plant-Microbe Interact., 10, 861-871.

Cock, J. H. (1985), Cassava: new potential for a neglected crop. Boulder, CO : Westview Press. 192 pp.

Dai, G. H.; Nicole, M.; Andary, C.; Martinez, C.; Bresson, E.; Boher, B.; Daniel, J. F. and Geiger, J. P. (1996), Flavonoids accumulate in cell walls , middle lamellae and callose-rich papillae during an incompatible interaction between Xanthomonas campestris pv. malvacearum and cottom. Physiol. Mol. Plant Pathol., 49, 285-306.

Flood, J.; Cooper, R. M.; Deshappriya, N. and Day, R. C. (1995), Resistance of cassava (Manihot esculenta) to Xanthomonas blight in vitro and in planta. Aspects Appl. Biol., 42, 277-284.

Fritig, B.; Kauffmann, S.; Dumas, B.; Geoffroy, P.; Kopp, M. and Legrand, M. (1987), Mechanism of the hypersensitivity response of plants. In: Evered, D. and Hermett, S. (ed.). Plant Resistance to Viruses. UK : Wiley Press. pp. 92-108.

Hahn, S. K.; Isoba, J. C. G. and Ikotun, W. C. (1989), Resistance breeding in root and tuber crops at the International Institute of Tropical Agriculture (IITA). Crop Protect., 8, 147-168.

Jorge, V.; Fregene, M. A.; Duque, M. C.; Bonierble, M. W.; Tohme, J. and Verdier, V. (2000), Genetic mapping of resistance to bacterial blight disease in cassava (Manihot esculenta Crantz). Theor. Appl. Genet., 101, 865-872.

Jorge, V.; Fregene Vélez, C. M.; Duque, M. C.; Tohme, J. and Verdier, V. (2001), QTL analysis of field resistance to Xanthomonas axonopodis pv. manihotis in cassava. Theor. Appl. Genet., 101, 564-571.

Kpemoua, K.; Boher, B.; Nicole, M.; Calatayud, P. and Geiger, J. P. (1996), Cytochemistry of defence responses in cassava infected by Xanthomonas campestris pv. manihotis. Can. J. Microbiol., 42, 1131-1143.

Pereira, L. F.; Goodwin, P. H. and Erickson, L. E. (1999), The role of a phenylalanine ammonia lyase gene during cassava bacterial blight and cassava bacterial necrosis. J. Plant Res., 112, 51-60.

Pereira, L. F.; Goodwin, P. H. and Erickson, L. E. (2000), Peroxidase activity during susceptible and resistant interactions between cassava (Manihot esculenta) and Xanthomonas axonopodis pv. manihotis and Xanthomonas cassavae. J. Phytopathology, 148, $575-577$ 
Restrepo, S.; Duque, M. C. and Verdier, V. (2000), Characterization of pathotypes among isolates of Xanthomonas axonopodis pv. manihotis in Colombia. Plant Pathology, 49, 680-687.

Rounsley, S. D. and Lin, X. (1997), Peroxidase isolog Arabidopsis thaliana. GenBank - direct submission. Accession Number 2342726.

Simon, P. (1993). Diversity and conservation of plant peroxidases. Plant Peroxidase Newslett., 1, 4-7.

Vidigal Filho, P. S.; Pequeno, M. G.; Scapim, C. A.; Vidigal, M. C. G.; Maia, R. R.; Sagrilo, E.; Simon, G. A. and Lima, R. S. (2000), Avaliação de cultivares de mandioca na região noroeste do Paraná. Bragantia, 59, 69-75.

Umemura, Y. and Kawano, K. (1983), Field assessment and inheritance of resistance to cassava bacterial blight. Crop Sci., 23, 1127-1132

Welinder, K. G. (1986), The plant peroxidase superfamily. In: Lobarzewski, J.; Greppin, H.; Penel, C. and Gaspar, T. H. (eds.). Biochemical, molecular and physiological aspects of plant peroxidases. Geneva : University of Geneva. pp. 3-13.

Received: July 06, 2001; Revised: November 12, 2001; Accepted: August 14, 2002. 